\title{
Hospitality studies and hospitality management: A symbiotic relationship
}

Alison Morrison, Kevin O'Gorman

Strathclyde Business School, University of Strathclyde, Cathedral Street, Glasgow, UK

\begin{abstract}
The key contribution of this paper is to critically analyse advances made since the introduction of hospitality as a higher education subject, to capture contemporary thinking, and to support the recognition of the intellectual benefits for hospitality management theory and practices of a curriculum informed from a social science-based studies perspective. The benefits of this interrelationship are demonstrated through the inclusion of an illustration informed by historical means of enquiry, which applies hermeneutical analysis and interpretation of St. Benedict's Rule (c. 530 A.D.). This serves to tangibly demonstrate the academic rigour, value, and educational gains achievable through a symbiotic relationship between hospitality studies and hospitality management.
\end{abstract}

\section{Keywords}

Hospitality studies; Higher education; Hospitality management

\section{Introduction}

The primary aim of this paper is to review the evolution of hospitality as an academic subject. It commenced life with a focus on hospitality management, defined by Brotherton and Wood (2000, p. 168) as: 'the management of hospitality in that one set of intellectual constructs and practices (management) are applied to another (hospitality)'. However, interestingly they stopped short of a reciprocal application. This represented a higher educational experience largely bounded within a narrow literature pertaining to business and management. Over time emerged a more inclusive hospitality studies approach which reflects on the connection of hospitality to society as a whole, and the location of the world of business and management therein (Lashley et al., 2007). This stance embraces literature and theory of multiple genre and discipline, including the social sciences. Further, it supports reciprocal application between the intellectual constructs and practices of both hospitality, and business and management. Hospitality subject development has now reached a point where there exists growing acceptance of the potential for, and value of, a symbiotic relationship between management and studies. As Morrison and O'Mahony (2003, p. 39) highlight, through such partnering there is: 'potential to generate new ways of thinking and a wider appreciation of world views on the concept of hospitality as broadly conceived'. Consequently, it has 
become evident that hospitality as an academic subject has advanced in its evolution: 'from being a topic simply for thematic investigation directly or indirectly for the study to management to one that also locates the study of hospitality as a significant means of exploring and understanding society' (Lashley et al., 2007, p. 186). Thus, the paper addresses some of the significant aspects that have shaped this subject development including: discourse relative to the higher education context; vocational and/ or liberal educational approaches; engagement with the social sciences; and the emergence and relationship between management and studies schools of thought. The paper argues that significant knowledge and intellectual advances can potentially be gained through a healthy inter- relationship between management and studies, drawing on a multi-disciplinary social science resource base. This aspect is demonstrated through the inclusion of a tangible illustration employing a historical means of enquiry to the context of religious hospitality. It provokes reflection, and evidence of the academic rigour and value of this approach. Ancient and classical texts, along with other relevant documentation, concerned with St. Benedict's Rule (c. 530 A.D.) have been critically analysed and interpreted. The research methodology applied is described and justified, and resultant findings, which form a taxonomy of principles of hospitality, are presented. This leads to consideration of the extent of change and continuity between this historical conception of hospitality and contemporary manifestations. Conclusions are drawn identifying and summarising issues pertaining to the subject development of hospitality in higher education. Thus, the key contribution of this paper is to critically analyse advances made since the introduction of hospitality as a higher education subject, capture contemporary thinking, and to support the recognition of the intellectual benefits for hospitality management theory and practices of a curriculum informed from a social science based studies perspective.

\section{Higher education context and hospitality}

The period of intellectual and cultural development that took place in the late mediaeval period led to the foundation of universities, initially offering higher education in the vocations. Thus, Tribe (2003) notes that down the centuries, universities have primarily survived as academies for training for the 'professions', such as law, medicine, and theology. Over time, these have adapted to the changing economic and social structures and volume of demand for skills, to include the likes of marketing, hospitality, and retailing. This serves to remind of the vocational remit of universities that has not changed over time, although the vocations they serve have.

Within this higher education context, the academic subject of hospitality management has been defined by the Higher Education Funding Council for England (1998, p. 15) as being: 'characterised by a core which addresses the management of food, beverages and/or accommodation in a service context'. The explicit intention is to prepare students for an occupationally circumscribed profession on graduation. Again this reflects a strongly vocational remit, which, as Symes and McIntyre (2000) observe, is one of the discourses that have helped to frame the university. However, Hyland (2001) highlights that the challenge for academic subjects, such as hospitality, has been the quest for a parity of esteem for vocational and academic subjects. He proposes that the way forward is to move away from the largely spurious nature of the distinction between a liberal and vocational education, 
and the avoidance of false divisions of body and mind, theory and practice, con- templative and productive knowledge that have led to an underpinning of the subordinate status of vocational oriented higher education. Tribe (2003, p. 471) adds a call for rebellion against the: 'impoverished instrumentality of the contemporary discourse about education and training', that appears to be adopting a strictly utilitarian, labour market driven relationship between higher education and graduate careers, which undervalues the contribution of university education in civilised society. This sentiment is echoed by academics within the subject of hospitality where the need for an escape from a 'tyranny of relevance' has been highlighted (Taylor and Edgar, 1996; Airey and Tribe, 2000), with Lashley (2004, p. 13) arguing that: 'the tyrants of the relevant should not be allowed to deflect them [academics] from responsibilities to empower students through education and the pursuit of knowledge'.

Thus, the rightful place of hospitality within a higher education framework is affirmed, as is emphasis on the partnership status of liberal and vocational education as the essence of what is understood to represent a university- level intellectual experience. This essence is aptly captured by Whitehead (1932, p. 9), in an essay welcoming the opening of Harvard Business School, discussing the role of universities he stated that: 'it preserves the connection between knowledge and the zest for life, by uniting the young and the old in the imaginative consideration of learning'.

\section{Hospitality across disciplinary boundaries}

The foregoing provides a useful contextualisation of hospitality in higher education from which evolutionary movement can be observed. Moreover, this is not unique to hospitality. It is also mirrored within its sister subject of tourism (Bibbings, 2005). A further example is in sociology, where Beardsworth and Keil $(1997$, p. 6) urge academics to be more flexible regarding the traditional boundaries of their discipline in order to encourage: 'interaction across boundaries thus opening novel areas of study, and moving previously marginal themes towards the centre of interest and into the mainstream of socio- logical debate'. Thus, questioning conventional wisdom and pushing at the subject boundaries should not be taken as a symptom of academic paranoia, or an intellectual crisis of confidence. On the contrary, it is surmised that such intellectual challenge, reflection and discourse are healthy, contribute valuable texture and structure to a maturing academic subject, and are essential for progress.

This vibrancy is reflected in contributions made by members of the hospitality management academic community over a quarter of a century. Specifically, it pertains to the relationship between business and management, and studies informed by the social sciences. Examples of key contributions are presented in Table 1, indicating a will for multi-disciplinary approaches, in particular relative to the social sciences, and a connection to a balanced range of world views that can inform hospitality management, and not solely the world of work. 
However, it could be argued that the hospitality academic community has been on the whole slower to recognise the subject development and intellectual benefits of cross-boundary disciplinary relationships than the social scientists. Indeed, there is an evergrowing body of academic literature of multiple genre that has sought out hospitality as a context in which to apply their particular disciplines. Illustrative examples of this are presented in Table 2. This attraction of social science academics to the study of hospitality is well illustrated by Beardsworth and Keil $(1997$, p. 6) relative to the consumption of food and drink: 'ythe act of eating lies at the point of intersection of a whole series of intricate physiological, psychological, ecological, economic, political, social and cultural processes. Such intersections present the human and social sciences with some of their most intriguing questions and challenges'. Furthermore, Lashley and Morrison (2004) identify the fascination of hospitality's complexity, operat- ing in a paradoxical framework within which polarities are apparent including: guest and host; peace and aggression; love and fear; friend and foe; free will and obligation; protection and containment; and reward and punishment. This emphasises the centrality of hospitality in society and as such, how hospitality can act as a lens through which to view, study and understand society (Lashley et al., 2007).

Thus, it is apparent that hospitality as a higher education academic subject is evolving and maturing from its beginnings as confined to management and industry. One reflection of hospitality's advancement towards an academic maturity is in the emergence of alternative schools of thought (Litteljohn, 1990; Jones, 2004). Within the contemporary hospitality academic community those that dominate are termed as 'studies' and 'management'. The former is derived from the social sciences applied to hospitality in its many guises, and not only within an industrial context as suggested by Jones (2004). It facilitates analysis of hospitality as business and as cultural phenomena; not necessarily unrelated; a view supported by Wood (1999), Lashley (2000), and Airey and Tribe (2000). The latter is concerned with hospitality as industry, commercial endeavour, and business and management therein (Morrison and Lynch, 2007). It has become apparent that the study of hospitality can usefully co-exist with that of hospitality management, as the difference between them is essentially one of emphasis (Jones, 2004). Hospitality studies allow for the intellectual pursuit of thesocial dimensions, alongside those of an economic nature. Consequently, opportunities are presented to surface novel areas worthy of study, and move previously peripheral hospitality themes towards the centre of interest and into the mainstream of the social sciences debate (Brotherton, 1999). Of significance is the manner in which it can challenge conventional wisdom and question accepted rhetoric by bring to bear: "multiple "eyes" all focused on the same phenomenon that is hospitality but arriving from diverse intellectual starting points and ways of seeing the world' (Lashley et al., 2007, p. 174).

In an effort to capture the essence of the hospitality studies, Morrison and O'Gorman (2006, p. 3) made a preliminary attempt to craft a working definition as follows: 
"It [hospitality] represents the cordial reception, welcome and entertainment of guests or strangers of diverse social backgrounds and cultures charitably, socially or commercially with kind and generous liberality, into one's home space to dine and/or lodge temporarily. Dependent on circumstance and context the degree to which the hospitality offering is conditional or unconditional may vary".

Thus, it is argued that the hospitality studies school of thought has the potential to contribute to: 'the creation of new knowledge that is not merely wed to unitary business, industry and/or management ways of knowing what is hospitality. The consequence is a move to more pluralistic and radical critical analysis, yielding significant intellectual gains' (Lashley et al., 2007, p. 174). Furthermore, it is not divorced from its relevance to hospitality management practices, as is illustrated in Section 4 of this paper. This provides evidence of the academic merits and intellectual gains that can potentially emerge, drawing on a historical means of enquiry to inform modern hospitality industry and business.

\section{St. Benedict's Rule: an illustration}

The research reported in this section addresses Lynch's (2005) appeal for the adoption of subjective and reflexive approaches to hospitality enquiry. It extends the work of O'Gorman (2007) who investigated textual evidence of hospitality within Classical Antiquity (generally accepted as the period between 770 B.C. and 529 A.D.). The focus is on St. Benedict's Rule (c. 530 A.D.), which was written in the period immediately following Classical Antiquity, and is recognised by Borias (1974) as one of the key foci for Christian and subsequent Western European hospitality. Limited research had been undertaken into the importance of St. Benedict's Rule: Andrade Cernadas (1991) investigated monastic hospitality in Spain during the twelfth century; and Ryan and McKenzie (2003) discussed the evolution of the monastic community of New Norcia in Western Australia as a tourist resort. However, research by O'Gorman and MacPhee (2006) identified that in the sixth century St. Benedict had codified the provision of hospitality within the monastic guesthouse. In St. Benedict's Rule the main focus for religious hospitality in chapter 53 is entitled De Hospitibus Suscipiendis - The Reception of Guests. Justification for such historical means of enquiry is provided by O'Connor (2005, p. 267) who states that: 'only once an understanding of hospitality's origins and its place in human nature is achieved can one expect to discover what hospitality means today, and more importantly what it will mean to those entering the industry in the future'.

The methodology adopted for the research is applied hermeneutical phenomenology within an interpretivist paradigm, because the methodology allows a greater understanding of the metaphysical social world in which this form of hospitality transaction was to operate. The approach is framed by the four methodological practices as proposed by Van Manen (1990), and developed by others including: Hein and Austin (2001), Alvesson and Skoldberg (2004), and Hayllar and Griffin (2005). First, in preparation for data analysis, thinking is oriented towards the nature of the lived experience at the period of time under investigation, whilst being as open and receptive as possible 
to the data analysis. This process includes setting aside any presuppositions, biases, and other knowledge of the phenomenon under investigation to gain a clear understanding. This first stage was partly achieved and greatly enhanced by translating the Latin text of the St. Benedict's Rule, and creating a new English version; this translation of chapter 53 is presented in Fig. 1. This enabled a fresh look to be taken at a familiar text, thus gaining a deeper understanding and more importantly allowed any bias from previous translations to be set aside. Within the English version of chapter 53 (Fig. 1), there are 24 statements or verses that deal with the reception and welcome of guests, and the subsequent provision of food, drink, and accommodation. There is a clear polarity between the closed monastic world and the secular world in general. By leaving the secular society, the monk sets up an alternative world in which people from the secular world might wish to share. Therefore, the ritual reception of guests was to play an important role by being both the bridge and the barrier between the two worlds. The first part of the chapter (verses 1-15) is focused on reception of guests and those travellers who arrive unexpectedly, the nature of the greeting they are to receive, and the subsequent hospitality that has to be offered to them. The rest of the chapter (verses 16-24) is pragmatic, and even restrictive, although certainly practical. Guests, it appears, are never in short supply and can arrive at any time, but there is a wish, inherent in the Rule, to minimise the disturbance caused to the community. In recognition of this there are three specific matters which are dealt with in these concluding verses: the guests' kitchen, their accommodation, and their communications with the monks.

In the second stage of the hermeneutical process, a dialogue with the text is developed, which leads the phenomenon into a deeper investigation in the hope of revealing something that is hidden. Importantly, May (1991) advises that as such documents present social reality and versions of events it is essential that comparison and cross-interpretation be undertaken to validate emerging understanding and themes. At this stage modern texts were used to provide this as well as commentary and analysis, for example, Bockmann (1988), Borias (1974), Fry (1981), Holzherr (1982), Kardong (1984), Regnault (1990), and Vogue (1977). The third stage consists of reflection, and"' according to Denzin (1989), it is in effect a process of reconstruction where the text is classified and reassembled into a coherent whole. This was enhanced by using a collection of mediaeval texts complied by Wolter (1880), allowing for a deeper interpretation of the essential themes by comparing interpretations of the text. During this stage five principles of hospitality emerged as clear divisions of both the Rule and contemporaneous monastic practice.

Throughout the fourth and final stage of the methodology, that of writing and re-writing, consideration was given to Caputo (1987) who notes that central to this is the procedure of asking questions of the text, and listening to it, in a dialogic form. Specifically, the research revealed a range of key principles associated with religious hospitality. During this time-consuming process of writing and re-writing subdivisions within the five principles emerged, these were critically compared for duplications and similarities. As part of the writing process the classical and mediaeval language contained within the principles was translated into more modern business terminology. In applying this methodology, the view of Hayllar and Griffin (2005) was supported when they assert that writing and reflection are symbiotic tasks. 
Through this research and analysis, a depth of understanding of the phenomenon of religious hospitality was gained. It enabled the construction and ordering of a taxonomy of hospitality principles as a coherent whole and in a style that is recognisable to modern professional hospitality managers. This taxonomy is presented in Fig. 2 . What is remarkable is that reconnecting with the past highlights significant relevance to the modern world of hospitality management arising from the research reported in this section. Analysis of the Rule of St. Benedict also demonstrates the illuminatory capacity of critical historical investigation, and the continuity of hospitality management practices over the last 1500 years. However, the purpose of this type of research is not to replicate the past, but to provide meaning, context, and greater understanding of the phenomenon of hospitality not previously realised. Importantly, for contemporary graduates of hospitality management, this form of historical research allows for the intellectual pursuit of social and cultural dimensions that transcend artificial disciplinary boundaries, and which provide a way of connecting with the origins of hospitality in order to enhance the learning of the professionals of tomorrow.

\section{Conclusions}

Within a higher education context, the journey from hospitality's historic origins and association primarily with management to a contemporary situation that supports the inter-relationship between and co-existence of, management and studies schools of thought has been traced, and academic advancement identified. Specifically, it recognises hospitality's 'late entrant' status as a university subject. Nevertheless, argument is presented to urge for a break-out from any apologetic or inferior stance relative to its inclusion in the 'academy' that has seemed to preoccupy the hospitality academic community over recent decades. In the twenty-first century, hospitality has established its place within higher education.

It represents a modern manifestation of a university experience that is designed to both prepare the professionals of tomorrow, and to contribute more widely to civilised society as a whole.

Furthermore, it has been established that a learning environment which embraces liberal and vocational approaches in balanced measures is wholly appropriate in this endeavour. A real challenge that confronts hospitality educationalists as the subject advances is the achievement of an appropriate blend of the liberal, reflective, and contemplative alongside those of the vocational, pragmatic, and practice educational processes. This represents a pluralistic approach that rebels against a unitary, utilitarian focus of education purely to satisfy vocational and industry imperatives. It forcibly defends the raison d'etre that structures a higher education experience which prioritises cerebral intellectual exploration, nurturing, and growth in the empowered pursuit of knowledge for knowledge's sake first, to then be found meaning and practical applications within the vocational context, as was demonstrated in the St. Benedict's Rule illustration. 
Within this context, there has been growing acceptance by academics of the intellectual and professional gains that could potentially emerge from exploring hospitality man- agement through multi-disciplinary enquiry drawing on the social sciences. For example, Lashley et al. (2007) advocate that this serves to overcome the bounded nature endemic to the academic field of hospitality management in order to address issues of the phenomenon of hospitality as broadly conceived. Thus, it is apparent that an ever increasing critical mass of contemporary hospitality academics has intellectually engaged in this process, albeit at a slower rate than their social science colleagues, and it could be taken as an indication of intellectual and academic subject advancement. Hopefully, current and future generations of hospitality higher educationalists will find this subject advancement contagious, and add their intellectual energies to such a rich and fertile field of study with abundant practical applications for higher education, management, and society as a whole. 


\section{References}

Alvesson, M. and Sköldberg, K. 2004 Reflexive Methodology: New Vistas for Qualitative Research. London: Sage Publications.

Andrade Cernadas, J.M. 1991 El Monasterio de Samos y La Hospitalidad Benedictina con el Peregrino. Studia Monastica 33:247-257

Airey, D., Tribe, J., 2000. Education for Hospitality, In: Lashley, C. and Morrison, A. (eds.), In Search of Hospitality: theoretical perspectives and debates, Butterworth-Heinemann, Oxford, pp.192-276.

Beardsworth, A., Keil, T., 1997. Sociology on the Menu, Routledge, London.

Ben Jelloun, T., 1999. French Hospitality: Racism and North African Immigrants, Columbia University Press, New York.

Bibbings, L., 2005. The Future of Tourism in Higher Education, Link 12, The Higher Education Academy, Hospitality, Leisure, Sport and Tourism Network, Oxford.

Böckmann, A., 1988. Xeniteia-Philoxenia als Hilfe zur Interpretation von Regula Benedicti $53 \mathrm{im}$ Zusammenhang mit Kapitel 58 und 66. Regulae Benedicti Studia. 14/15:131-144.

Borias, A.,1974. Hospitalité Augustinienne et Bénédictine. Revue de Histoire de Spiritualité. 50:3-16.

Brotherton, B., 1999. Hospitality management research: towards the future? In Brotherton, B. (Ed.), The Handbook of Contemporary Hospitality Management Research, John Wiley and Sons, Chichester, pp.531-543.

Brotherton, B., Wood, R., 2000. Hospitality and Hospitality Management, In: Lashley, C. and Morrison, A. (eds.), In Search of Hospitality: theoretical perspectives and debates, Butterworth-Heinemann, Oxford, pp.134-156.

Brownell, J.,2001. Gender and communication in the hospitality industry. In: L. Arliss and D. Borisoff (eds.), Women and Men Communicating: Challenges and Changes, Harcourt Brace Jovanovich College, New York, pp.193-216.

Caputo, J.D. 1987. Radical Hermeneutics. Repetition, Deconstruction, and the Hermeneutic Project. Bloomington: Indiana University Press.

Cassee, E., 1983. Introduction, in Cassee, E. and Reuland, R. (Eds.) The Management of Hospitality, Pergamon, Oxford, pp. xiii-xxii.

Denzin, N.K. 1989. Interpretive Interactionism. Newbury Park: Sage.

Derrida, J. 1998. Hospitality, Justice and Responsibility: A Dialogue with Jacques Derrida. In R.

Kearney and M. Dooley (eds.) Questioning Ethics: Contemporary Debates in Philosophy. Roudedge, London.

Derrida, J. 2000. 'Hostipitality', Angelaki: Journal of the Theoretical Humanities, 5, 3:3-18.

De Vaux, R. 1961. Ancient Israel. Darton, Longman \& Todd, London.

Ellis, S.J.R. 2004a. The distribution of bars at Pompeii: archaeological, spatial and viewshed analyses. Journal of Roman Archaeology, 17:371-384.

Ellis, S.J.R. 2004b. The Pompeian Bar: archaeology and the role of food and drink outlets in an classical community. Food \& History, 2:41-58.

Fry, T., 1981. RB 1980: The Rule of St. Benedict, In Latin and English with Notes. Liturgical Press. Collegeville.

Goffman, E., 1969. The Presentation of Self in Everyday Life, Anchor Books, New York.

Hayllar, B., and Griffin, T. 2005. The Precinct Experience: a phenomenological approach. Tourism Management 26:517-528.

Heal, F., 1990. Hospitality in Early Modern England, Oxford University Press, Oxford.

Hein, S.F. and Austin, W.J. 2001. Empirical and Hermeneutic Approaches to Phenomenological Research in Psychology: A Comparison. Psychological Methods 6:3-17.

Higher Education Funding Council for England, 1998. Review of Hospitality Management, HEFCE, London. 
Holzherr, G., 1982. Die Behediktsregel: Eine Anleitung Zu Christlichem Leben. Benziger, Verlag. Hyland, T., 2001. Vocationalism, Work and the Future of Higher Education, Journal of Vocational Education and Training, 53, 4:677-684.

Jones, P. (1998) Editorial. International Journal of Hospitality Management 17:105-110.

Jones, P., 2004. Finding the Hospitality Industry? Or Finding Hospitality Schools of Thought?, Journal of Hospitality, Leisure, Sport and Tourism Education, 3,1:33-45.

Kardong, T.G., 1984. Together Unto Life Everlasting, An Introduction to the Rule of Benedict. Assumption Abbey Press, North Dakota.

Lashley, C., 2000. Towards a Theoretical Understanding, In: Lashley, C. and Morrison, A. (eds.), In Search of Hospitality: theoretical perspectives and debates, Butterworth-Heinemann, Oxford, pp.1-16.

Lashley, C., 2004. Escaping the Tyranny of Relevance: some reflections on hospitality management education, paper presented at CAUTHE 2004, Alice Springs.

Lashley, C., Morrison, A., 2004. Turning a Customer into a Friend: commercial applications of the emotions of hospitality, Hospitality Review, 5, 4:31-36.

Lashley, C., Lynch, P., Morrison, A., 2007. Hospitality: a social lens, Elsevier, Oxford.

Litteljohn, D., 1990. Hospitality research: philosophies and progress, In: Teare, R., Moutinho, L. and Morgan, N. (eds.), Managing and Marketing Services in the 1990s, Cassell, London, pp.209232.

Lynch, P.A. 2005 Sociological Impressionism in a Hospitality Context. Annals of Tourism Research 32:527-548.

Matthews, V. H. (1991) 'Hospitality and Hostility in Judges 4' Biblical Theology Bulletin 21:13-21.

Matthews, V.H. (1992) "Hospitality and Hostility in Genesis 19 and Judges 19." Biblical Theology Bulletin 22,1:3-11.

May, T. (1991) Social Research: Issues, Methods and Process. Open University Press, Buckingham.

Mayr-Harting, H. 1988 The Foundation of Peterhouse, Cambridge (1284), and the Rule of Saint Benedict. The English Historical Review, 103:318-338.

Morrison, A., O'Gorman, K., 2006. Hospitality Studies: Liberating the Power of the Mind, paper presentation, CAUTHE2006, Victoria University, Melbourne.

Morrison, A., O'Mahony, B., 2003. The Liberation of Hospitality Management Education, International Journal of Contemporary Hospitality Management, 15, 1:38-44.

O'Connor, D., 2005. Towards a new interpretation of 'hospitality', International Journal of Contemporary Hospitality Management, 17, 3:267-271.

O'Gorman, K.D. 2006. The legacy of monastic hospitality: 1 The Rule of Benedict and rise of Western monastic hospitality. The Hospitality Review. 8, 3:35 - 44.

O'Gorman, K.D. 2007 Dimensions of Hospitality: Exploring Ancient Origins. In Advances in Tourism Research, Hospitality: A social lens. Lashley, C., Morrison, A., Lynch, P. (eds) Oxford: Elsevier.

O'Gorman, K.D. and MacPhee, E. 2006. The legacy of monastic hospitality: 1 The Lasting Influence. The Hospitality Review. 8, 4:16-25.

Reece, S. (1993) The Stranger's welcome: oral theory and the aesthetics of the Homeric hospitality scene. University of Michigan Press, Michigan.

Regnault, L., 1990. La Vie Quotidienne de Pères du Désert en Egypte au IVe Siècle. Hachette, Paris.

Ryan, M.M., McKenzie, F.H. 2003 A monastic tourist experience: the packaging of a place. Tourism Geographies 5:54-70.

Slattery, P., 1983. Social scientific methodology and hospitality management, International Journal of Hospitality Management, 2, 1:9-14.

Symes, C., McIntyre, J. (eds.), 2000. Working Knowledge. The New Vocationalism in Higher Education, SRHE/Open University Press, Buckingham.

Taylor, S., Edgar, D., 1996. Hospitality research: the emperor's new clothes?, International Journal of Hospitality Management, 15,3:211-27. 
Telfer, E.,1996. Food for Thought, Philosophy of Food, Routledge, London.

Tribe, K., 2003. Demand for Higher Education and the Supply of Graduates, European Educational Research Journal, 2, 3:463-471.

Vogüé, A., 1977. La Règle de saint Benoît, VII, Commentaire Doctrinal et Spiritual. Les editions du Cerf, Paris.

Whitehead, A.N. 1932. Aims of Education: and other essays. London: Williams \& Norgate

Wolter, M., 1880. Praecipua Ordinis Monastici Elementa. Desclée, Brugis.

Wood, R., 1982.

Wood, R., 1999. Traditional and alternative research philosophies, in Brotherton, B. (Ed.), The Handbook of Contemporary Hospitality Management Research, John Wiley, Chichester, pp.3-18.

Woods, R., 1991. Hospitality's History: who wrote what about when, Cornell Hotel and Restaurant Administration Quarterly, 32,2:89-95. 


\section{Tables and Figures}

Table 1: Examples of key contributions to hospitality subject development

\begin{tabular}{|l|l|}
\hline Author & Contribution \\
\hline Wood (1982) & Argues for sociological approaches to the study of hospitality management. \\
\hline Cassee (1983) & $\begin{array}{l}\text { Emphasises the interrelatedness of the hospitality industry with the outside } \\
\text { world. }\end{array}$ \\
\hline Slattery (1983) & $\begin{array}{l}\text { Advocates the application of existing social science theory to hospitality } \\
\text { management. }\end{array}$ \\
\hline Litteljohn (1990) & $\begin{array}{l}\text { Allows for an approach to hospitality industry research that draws on the } \\
\text { social sciences. }\end{array}$ \\
\hline Jones (1998) & Recognises a need for multi-disciplinarity and the difficulty in achieving it. \\
\hline Airey and Tribe (2000) & $\begin{array}{l}\text { Points to the preoccupation with the world of work rather than the many } \\
\text { disciplines or fields of enquiry that help explain hospitality. }\end{array}$ \\
\hline Lashley et al. (2007) & $\begin{array}{l}\text { Identifies a contemporary willingness of the academic community to } \\
\text { extend the conception of the hospitality subject boundaries, and associate } \\
\text { this process as very positive for the subject development and its consequent } \\
\text { academic standing. }\end{array}$ \\
\hline
\end{tabular}


Table 2: Illustrative examples of disciplines engaging in research into the phenomenon of hospitality.

\begin{tabular}{|c|c|c|}
\hline Field & & Authors \\
\hline Anthropology & $\begin{array}{l}\text { Observes current practices among the desert Bedouin of } \\
\text { southern Israel and Jordan clearly indicating the importance and } \\
\text { centrality of the hospitality practices to their way of life }\end{array}$ & $\begin{array}{l}\text { De Vaux } \\
(1961)\end{array}$ \\
\hline Archaeology & $\begin{array}{l}\text { Interprets and excavates the use of commercial hospitality } \\
\text { buildings and structures, in order to understand more about how } \\
\text { people lived in historical locations. }\end{array}$ & $\begin{array}{l}\text { Ellis }(2004 \mathrm{a} \text {; } \\
\text { 2004b) }\end{array}$ \\
\hline Biblical Studies & $\begin{array}{l}\text { Explores the origins of hospitality demonstrate that hospitality is } \\
\text { not a simple concept it contains deeply rooted cultural norms. }\end{array}$ & $\begin{array}{l}\text { Matthews } \\
(1991 ; 1992)\end{array}$ \\
\hline Classics & $\begin{array}{l}\text { Uses the theme of hospitality to give significantly richer } \\
\text { understanding of the structure of the Homeric epics, by } \\
\text { demonstrating that successive oral poets who redacted the } \\
\text { Homeric poems, used the concept of hospitality as recurrent } \\
\text { them. }\end{array}$ & Reece (1993) \\
\hline Deconstruction & $\begin{array}{l}\text { Defines hospitality as inviting and welcoming the 'stranger'; } \\
\text { however this takes place on two levels: the personal level where } \\
\text { the 'stranger' is welcomed into the home; and at the level of } \\
\text { individual countries. Using the conceptual possibility of } \\
\text { unconditional hospitality to understand and to inform what is } \\
\text { going on today in our world. }\end{array}$ & Derrida (2000) \\
\hline Gender Studies & $\begin{array}{l}\text { Observes that symbols, verbal and non-verbal communication, } \\
\text { and value of sociability and physical attractiveness, contributes } \\
\text { to a sexualised work environment that is likely to encourage and } \\
\text { draw attention to gender-specific behaviours }\end{array}$ & $\begin{array}{l}\text { Brownell } \\
(2001)\end{array}$ \\
\hline Philosophy & $\begin{array}{l}\text { Pursues the reality and principles underpinning hospitality as a } \\
\text { phenomenon }\end{array}$ & Telfer (1996) \\
\hline $\begin{array}{l}\text { Post Colonial } \\
\text { Theory }\end{array}$ & $\begin{array}{l}\text { Investigates the politics of hospitality exploring issues including } \\
\text { democracy, citizenship, social exclusion, xenophobia and racism } \\
\text { to reveal the ethics and politics of hospitality and the status of } \\
\text { the stranger, visitor, migrant, asylum seeker and refugee }\end{array}$ & $\begin{array}{l}\text { Ben Jelloun } \\
\text { (1999) }\end{array}$ \\
\hline Social History & $\begin{array}{l}\text { Investigates role of hospitality in society in particular in forming } \\
\text { communities. }\end{array}$ & Heal (1990) \\
\hline Sociology & $\begin{array}{l}\text { Constructs and deconstructs the role, meaning and symbolism of } \\
\text { hospitality in society. }\end{array}$ & $\begin{array}{l}\text { Goffman } \\
(1969)\end{array}$ \\
\hline
\end{tabular}




\section{Figure 1: Rule of Benedict Chapter 53 (0'Gorman 2006)}

${ }^{1 .}$ All guests who arrive should be received as if they were Christ, for He himself is going to say: "I came as a stranger, and you received $\mathrm{Me}^{\prime \prime} ;{ }^{2}$ and let due honour be shown to all, especially those who share our faith and those who are pilgrims. ${ }^{3 .}$ As soon as a guest is announced, then let the Superior or one of the monks meet him with all charity, ${ }^{4}$ and first let them pray together, and then be united in peace. ${ }^{5}$ For the sign of peace should not be given until after the prayers have been said, in order to protect from the deceptions of the devil. ${ }^{6 .}$ The greeting itself, however, ought to show complete humility toward guests who are arriving or departing: ${ }^{7}$ by a bowing of the head or by a complete prostration on the ground, as if it was Christ who was being received. ${ }^{8}$ After the guests have been received and taken to prayer, let the Superior or someone appointed by him, sit with them. ${ }^{9}$. Let the scripture be read in front of the guest, and then let all kindness be shown to him. ${ }^{10}$. The Superior shall break his fast for the sake of a guest, unless it happens to be a principal fast day; ${ }^{11}$ the monks, however, shall observe the customary fasting. ${ }^{12}$. Let the Abbot give the guests water for their hands; and ${ }^{13 .}$ let both Abbot and monks wash the feet of all guests; ${ }^{14}$. after the washing of the feet let all present say this verse: "We have received Your mercy, O God, in the midst of Your church". ${ }^{15}$. All guests should be received with care and kindness; however it is when receiving the poor and pilgrims that the greatest care and kindness should be shown, because it is especially in welcoming them that Christ is received.

16. There should be a separate kitchen for the Abbot and guests, so that the other monks may not be disturbed when guests, who are always visiting a monastery, arrive at irregular hours. ${ }^{17}$. Let two monks who are capable of doing this well, be appointed to this kitchen for a year. ${ }^{18 .}$ They should be given all the help that they require, so that they may serve without murmuring, and on the other hand, when they have less to occupy them, let them do whatever work is assigned to them. ${ }^{19}$. And not only in their case but a similar arrangement should apply to all the jobs across the monastery, ${ }^{20}$. so that when help is needed it can be supplied, and again when the workers are unoccupied they do whatever they are required to do. ${ }^{21}$ Responsibility for the guest house also shall be assigned to a holy monk. ${ }^{22}$. Let there be an adequate number of beds made up in it; and let the house of God be managed by wise men and in a wise manner. ${ }^{23}$. On no account shall anyone who is not so ordered associate or converse with the guests, ${ }^{24}$. but if he should meet them or see them, let him greet them humbly, as we have said, ask their blessing and pass on, saying that he is not allowed to converse with a guest. 


\section{Figure 2: Taxonomy of hospitality principles derived from a hermeneutical analysis and evaluation of St Benedict's Rule}

\section{Business Principles}

- Guests are central to the purpose of the business

- When providing service the management and staff are separate from the society that they are providing service to

- The level of service offered is determined by the type of the business

- Businesses have a responsibility for the health, safety and security of the guests

- Management and staff should display personal integrity and be practically competent

- The business, its management and staff must maintain a professional relationship with guests at all times

\section{Guest Principles}

- Guests are to be treated with respect

- Welcoming gestures and language are as important as the acts of service.

- Delays in the provision of hospitality are a hardship for the guests

- Guests should not feel that the provision of service is an inconvenience to the business.

- The difficulties in providing the service are of no interest to guests

- Providing service and improving it is more important to guests than providing additional hospitality

\section{Hospitality Provision Principles}

- All guests are welcome

- Service is offered at different levels

- Hospitality is offered based on the needs of the guests at the time

- There must be provision of hospitality for guests with special needs

- Provision must be for basic needs (food, drink and accommodation) as well as other needs as required

- Food and drink should be available at all times for guests as they arrive

\section{Staffing Principles}

- The person providing the service is seen by the guest as representing the business as a whole.

- Personal characterises of staff must be genuinely disposed to providing service

- There is a need for specialised staff as well as multi-skilled staff

- Staff roles should be clearly defined to indicated which staff interact with guests and how

- The level of staffing needs to match the business demand

- Staff should maintain their dignity in providing service: service not servility

- Staff must not cause the guests unnecessary disturbance

\section{Management Principles}

- Hospitality managers must be professional and competent

- Managers have a responsibly to balance the provision of service the requirements of the business

- Managers as well as having responsibly to manage the business also have to be seen by the guests as the host

- Both expected demand and unexpected demand need to be prepared for

- Guest and staff areas should be separated and access controlled

- Staff who are providing hospitality must be fully resourced and supported by the management team

- The management is to blame if staff do not have the skills or equipment to carry out their duties

- Teamwork is important for efficient service 